\title{
15
}

\section{Reconciling Opposing Discourses: Narrating and Teaching the Cold War in an East-German Classroom}

\author{
Eva Fischer
}

\section{Introduction}

A few years ago, a long-term study showed that German Reunification has produced highly ambivalent stances among many citizens of the former German Democratic Republic (GDR): While most Eastern Germans in their 30s view the reunification as positive and identify with the Federal Republic of Germany (FRG), they have also continued to feel connected with the GDR. Some have remained critical towards capitalism, for example, and most prefer the GDR's welfare system (Förster 2011, 144, 189 and 233; Förster 2008, 153 ${ }^{1}$ ). Ambivalence also characterises academic debates about the Cold War. The downfall of the Soviet Union has destabilised binary patterns of interpretation - both in East and West and Cold War history is discussed more controversially than ever (Erll 2011 , 3). The various positions have been categorised as traditionalist, revisionist and post-revisionist. Stemming from the era of the Cold War itself, these different schools of thought used to be primarily concerned

E. Fischer $(\bowtie)$

Independent Researcher, Oldenburg, Germany 
with assigning responsibility for the conflict. While some argue that the question of guilt has become obsolete in the post-Cold War era (Jarausch, Ostermann and Etges 2017), others insist that it is still dominant (e.g. Lundestad 2014). The topics of debate, in any case, have broadened. They include such questions as whether the conflicts between East and West were more crucial as compared to those between North and South, and whether the fear of nuclear war or the development of the welfare state was more characteristic of the era (Iriye 2014).

While the academic community is far from reaching a consensus, history teachers from the former GDR seem to sense the presence of a traditionally western hegemonic discourse. They often do not seem to view themselves in legitimate speaker positions when interpreting the past, especially in the presence of a West German. ${ }^{2}$ They are, as Sabine Reh has observed, under an implicit pressure to justify themselves and to express 'confessions' and 'commitments' (Reh 2003, 19, 169). Reh partly traces this back to the fact that, after Reunification, the education system of the GDR became a major target of critique in a western-dominated discourse on education that was interwoven with broader academic discourses on East German identity (transformation) (ibid., 18). As public education in the East was viewed as an emblem of a repressive political system, its teachers were believed to have been either disenfranchised or part of the regime (ibid., 111-119). ${ }^{3}$

On the grounds of these insights, this case study will explore an East German history teacher's 'talking' and 'doing' (Ahlrichs et al. 2015) in relation to Cold War history. I will investigate how the teacher, Julia ${ }^{4}$, perceives and positions herself within the current discourse on the Cold War in the presence of a West German researcher, what strategies she develops to construct coherent narratives and where she (re)produces the limits of what can be said (Foucault 1969). By explicitly looking at different contexts and social situations, I acknowledge recent trends in memory studies that view memory as context-bound (Ahlrichs et al. 2015) and have replaced the 'individual' versus 'collective' dichotomy with the notion of 'entangled' memory (Feindt et al. 2014, 24-44).

Born in 1956, Julia experienced working life both before and after reunification, beginning her career in the GDR and continuing to work once her state had become part of the reunited FRG. According to Bernd Lindner, members of this 'integrated generation' are characterised by their 
full social integration into GDR structures. They grew up in a divided country, experienced the development of a GDR youth culture, and benefited from social reforms in the 1970s. Most of them therefore identified with their state and had a positive image of it (Lindner 2003). 'Overrun' by the collapse of the GDR, however, the 'integrated generation' is ascribed a 'twofold horizon of experience', as its members have spent much of their adulthood in the Western system (Welke 2012, 75). By focusing on a teacher from this generation, I follow Barbara Christophe's suggestion to view history teachers 'in their double function as members of memory cultures and as professionals specialised in conveying state-approved patterns of interpretation' (p. 256 of this volume; see also Chapter 17).

Thematically, I will focus on the immediate post-1945 period, the interpretation of which is relevant for memory politics in divided Germany. The GDR officially adopted the image of the 'Soviet liberators' from National Socialism (Kleßmann 2010; Müller 2008), while the FRG insisted on the concept of political defeat and accused the GDR of having upheld a totalitarian system. The GDR, in turn, presented itself as the truly anti-fascist German state in which the entire Nazi elite had been eliminated. They claimed that the Western allies, in contrast, had failed to overthrow old structures, and that the FRG was thus the immediate successor of Nazi Germany. It was only with the social movements of the 1960s that some of this criticism was in fact adopted by left-winged activists in the West, who demanded structural reforms (Kleßmann 2010).

As a hinge between World War II and the Cold War, the post-1945 period has also been a major issue of post-reunification historiographical discourse. Proving the ultimate failure of the Eastern system, the collapse of the GDR revealed the full ambivalence of the year of 1945 (ibid; Möller 1995). While official GDR interpretations of history have become obsolete, historians have put a new focus on individual experiences of German victimhood during the post-World War II period (Kleßmann 2010, 7-8). Debates about the Cold War have also renewed both traditionalist and revisionist arguments regarding the role of the superpowers during this phase (Lundestad 2014).

Looking at a variety of social situations, this study explores Julia's repertoire of strategies with which to create narratives about an ambiguous past. This approach requires different types of data. We audio-recorded and transcribed a biographical interview as well as a guided interview on 
the basis of textbook passages about the Cold War. We further videorecorded two history lessons and had them transcribed. ${ }^{5}$ As I will outline, Julia produces different accounts of the Cold War while re-employing narrative templates (Wertsch 2002, 60-62) that interconnect political history and the personal sphere. Despite her awareness of Cold War controversies, her (re)actions imply a deep insecurity regarding the social legitimacy of her positions. However, she also engages in resistance.

\section{Methods}

The biographical interview addresses Julia as a private person, serving to access her life story. The construction and constant revision of our life stories enables us to ascribe meaning to our lives and 'to exist in the social world with a comfortable sense of being a good, socially proper, and stable person' (Linde 1993, 3). Attempting to create a sense of coherence and agency, we draw on unspoken, culture-specific supplies of expected life events and acceptable reasons for our decisions (ibid., 3, 11, 19 and 93). The life story approach is particularly promising for this case study: Since Julia is a member of the 'integrated generation', the cultural supply-kit has changed in the course of her life. Especially in the presence of a West German, she may feel required to re-adapt her story, which can provide hints at how she perceives her own position in discourse. The rather personal set-up of the biographical interview may thus not be as 'innocent' as it seems (cf. Reh 2003, 17-18). Following the recommendations by Fritz Schütze, we started the interview with an open question and asked followup questions only after Julia had finished speaking (Schütze 1982, 570).

The textbook-related interview addresses Julia in her professional role as a history teacher. Using a questionnaire, we specifically asked her what she thinks about selected ambivalent passages about the origins of the Cold War (cf. Baier, Christophe und Zehr 2014) and how useful she finds them for class.

The classroom, as a third social context, places Julia in a position of relative power. The more she engages in discussion and textbook work, however, the less she is in control over the course of events and elements entering from outside discourses (see Binnenkade 2015). I will therefore 
compare situations that vary in their forms of interaction: first, situations in which Julia talks (almost) uninterruptedly to the class; second, situations with more lively dialogues; third, a situation in which Julia interacts with both the students and the textbook, the latter providing an additional conveyer of narratives ${ }^{6}$.

I will draw on Wertsch's (2002, 60-62) concepts of 'specific narratives' and 'schematic narrative templates' to interpret the data. 'The former refers to stories that people construct in order to make sense of specific events of the past. The latter describes generalised narrative forms and patterns that underlie a range of stories. By exploring the narrative templates employed by Julia, I aim to identify continuity across the different contexts and situations.

\section{Life Story: Connecting Political and Family History}

Julia's life story is characteristic of the 'integrated generation'. She describes her childhood as 'free' and 'cheerful', ${ }^{8}$ detailing how she went through the entire GDR school system. She was given special attention because of her father's position with the police, and received a university scholarship. As 'the first year to benefit from the social reforms', Julia and her husband could afford a flat and two children while studying. ${ }^{9}$ Her attitude towards the GDR is ambivalent. She experienced its collapse as 'enormous'. ${ }^{10}$ ' $[\mathrm{Y}]$ ou had these questions in mind. What will happen? How will things continue?' ${ }^{11}$ As a history teacher, she was 'close to a coma' by mid-November 1989, not knowing what to teach and test anymore. ${ }^{12}$ Unlike her father, who was too old 'to fully enjoy' the new situation, ${ }^{13}$ however, Julia adapted to life after Reunification. While continuing her career as a teacher, she read West German literature in order to learn 'what's going on on the other side'. ${ }^{14}$ She also retrospectively denounces her education in the GDR through the public system as a form of indoctrination: Her teachers 'taught the curriculum' and 'clearly positioned' themselves. ${ }^{15}$ At university, they studied 'two years of GDR history' with 'dates, dates, dates [about] the founding of the GDR and of the SED 
[Socialist Unity Party of Germany]', all of which was 'written by followers, of course', and represented 'uncritically and heroically'. ${ }^{16}$ Professors blocked any challenging questions, and Julia 'simply absorbed what they said'. ${ }^{17}$ When talking about the 1970 movie The Strawberry Statement about student protests in the US, she provides an explanation which reads like a self-justification for why she and her university friends did not rebel more: 'We were probably too mellow, thinking "oh well, we are pretty well off". ${ }^{18}$

The division of the country is a prominent element of Julia's life story. She is the daughter of East Prussian refugees who had 'put down new roots' in her East German home town ${ }^{19}$ while part of her mother's family had settled in the West. 'Reorientating' himself, her father became a painter and then joined the GDR police force ${ }^{20}$, which implies a significant occupational and social advancement in the system. Because of the father's position, Julia's family was officially forbidden to maintain any contacts in the West. Since her mother's relatives lived there, this was a subject of constant tension between Julia's parents. ${ }^{21}$

What strategies does Julia employ to construct coherence in a life story that is characterised by division and ambivalence? Looking at two passages from the interview, I argue that she constructs her family history analogous to German history by intertwining the narrative templates of 'family and nation', 'victim' and 'reconciliation'. In the first passage, Julia talks about her father's position as a police officer and its consequences for their family life:

(1) ${ }^{22}$ Er hat sich immer nur gewundert, dass das mit [...] der Beförderung bei ihm nicht hingehauen hat. [...] Und er schob das dann immer auf diesen Punkt [dass die Familie Kontakte in den Westen hatte] (2) Und das, denke ich, ist so ein Zeichen für diese Sa/ für diese Zeit, für das Leben, was dann in Deutschland so/ oder in der DDR so eingekästelt war (3) Dass man so nach außen keine Beziehungen pflegen durfte [...]. (4) Und wenn dann die Großmutter mal zu Besuch war, dann suchte meine Mutti einen Tag aus, wo der Vater zur Schicht war [...]. Und dann war die mal für zwei, drei Stunden da, also und dann war es das (5) Also daran, denke ich, konnte man bei uns in der Familie sehen, wie gespalten [...] das eigentlich war und wie schlimm (6) Denn so eine Familie auseinander zu reißen, das 
ist/ durch diese Grenze, das ist wirklich schlimm gewesen. (7) Und, und das hat man eben bei der Mutter gemerkt. (8) Und ich denke, die hat da auch so einen richtigen Lebensschmerz gehabt, die ist mit 48 Jahren verstorben. [...] (9) Ähm, puh, das ist/ gibt viele Ursachen, aber ich denke, das ist auch eine da mit, dass sie da nicht so, eben nicht glücklich [...] war. $^{23}$

(1). He always wondered why [...] he was never promoted [...] and he always blamed it on [the fact that the family had contacts in the West]. (2) And this, I think, is indicative of those times and of that life that was so restricted in Germany, or in the GDR. (3) That you weren't allowed to have any outside contacts. [...] (4) When my grandmother was in town, my mother would pick a day when my father had shift-work, and my grandma [...] would stay with us for two, three hours and that was it. (5) From that, I think, you could see in our family how divided [...] this really was and how awful. (6) Because to tear apart a family by this border was really awful. (7) And you could see that with my mother. (8) I believe she had a really hard life. She died at the age of 48 [...] (9) There are many reasons, but I think one of them was that she just wasn't happy there.

The account merges political and family history by relying on the theme of division and a strategy of obscuring. On a linguistic level, the merge is epitomised in the phrase 'you could see in our family' (5), where the demonstrative pronoun 'das' (this) could refer to the family, the country, society and culture, or all of them. Similarly, the phrase 'to tear apart a family' (6) does not specify an agent. On the basis of this interplay, Julia describes the consequences of the division as 'awful' and 'really awful' (5-6) and even connects them to her mother's early death (7-9); again, the word 'there' in 'she just wasn't happy there' could refer either to the family or the state, thus connecting the two. Against this background, Julia employs the narrative template of 'victim' to describe how her father was being disadvantaged in his career as a result of having contacts in the West (1).

In a later passage, the father's role changes from being a victim of division to being an active obstacle of 'reconciliation', which represents another narrative template: 
(10) Und dann haben wir es ja geschafft, dass sich die West- und die Ostverwandtschaft äh wieder trifft. Das war '94. (11) Da hatten wir sie dann mal am Tisch [...] dass man diesen, diesen Bruch versucht zu beheben. [...] (12) Wir hatten [meinem Vater] gesagt: 'Es kommt dein Schwager [...] und deine Schwägerin' - 'Oh nee [...]. Kann ich nicht, halte ich nicht aus'. (13) Da haben wir gesagt: 'Du, das müssen wir jetzt einfach versuchen'. ${ }^{24}$

(10) We managed to arrange a reunion of the Western and Eastern relatives [...] in 1994. (11) We had them all at one table [...] to try and resolve the divide [...]. (12) We had said [to my father]: 'Your brother- and sister-inlaw are coming' - 'Oh, no, [...] I can't bear it'. (13) And we said: 'We just have to try'.

(14) Also mein Vater wollte das nicht einrühren. (15) Das haben wir eingerührt, einfach weil wir neugierig waren und weil wir das nicht verstehen wollten, dass sich Familien so trennen [...]. (16) Das kann ich bis heute nicht. Wenn ich mich mit jemandem zanke, dann kann das sein. Aber dann muss man irgendwo den Punkt finden [...]. (17) Und ähm das fand sich dann eben. (18) Die sind so aufeinander zu gegangen so wie Katzen und sich umschlichen und dann haben sie sich doch auf die Schultern geklopft [...]. Und da war alles gegessen, (19) da [...] konnte man sich an den Tisch setzen und in Ruhe reden und ähm, ja, und dann wurden auch so Jugenddummheiten rausgekramt. [...]. (20) Und das hätte noch mehr gebraucht davon [...]. So, aber wenigstens der Punkt, dass sie sich alle finden und sagen: 'Ja, ausgestanden. So'. ${ }^{25}$

(14) My father didn't want it (15). We initiated it, simply because we were curious and because we didn't want to accept that families split up like that. [...] (16). I still cannot. It might be possible if I argue with someone. But eventually you have to find a point [...] (17). And it was found then (18). They approached each other like cats, tiptoeing around each other, but finally they patted each other's shoulders. And the subject was closed (19). We were able to sit down at the table and talk calmly, and youthful follies were dug out (20). More of that would have been needed [...] but at least there was this point where everyone comes together and says: 'All right; let's put it all behind us'. 
While Julia describes herself and her siblings as putting a lot of effort into re-uniting the family, their father, who 'didn't want it' (14), now appears as a defender of division. The shift in the father's role is possible because of the ambiguous interconnection of political and family history in both passages, which does not clearly assign responsibilities. The narrative here is again constructed around the theme of division, evoked by the terms 'Bruch' (break/divide) (11) and 'trennen' (split up) (15). The tensions in the family are released when finally 'everyone comes together' (20). According to Julia's narrative, the reconciliation of the family is thus intrinsically entwined with the reunification of the country.

\section{A Textbook-Related Interview: 'Sometimes the West is as Good as the East'}

The template of 'reconciliation' recurs in the context of the guided, textbook-related interview. First of all, it expresses itself in Julias postrevisionist view of the Cold War. On the basis of a textbook passage that is ambivalent about assigning responsibility for the conflict's origins, she was asked whom she holds responsible: 'I believe each political system contributed its share by defining certain spheres of control'. ${ }^{26}$ '[It was about] resources and also markets. Ultimately, it was about money in the economy'. ${ }^{27}$ Distancing herself from both traditional Eastern and traditional Western narratives, Julia thus opts for a compromise position. In another instance, she reconciles the Western perspective by constructing a narrative that raises the West to the moral level of the East. While discussing a textbook excerpt about the policies and considerations of the commanders in the British and American occupation zones, the interviewer asks Julia whether she believes in a German consensus regarding the role of the Western allies. Julia replies:

(21) Ich denke eher, das wird sehr kontrovers betrachtet. Die einen haben solche/ Es gibt doch eine Erfahrungswelt. Ähm und dann liegt es noch ähm sehr im Auge des Betrachters, auf welcher Seite der Grenze er groß geworden ist. Da gibt es überhaupt noch keinen Konsens. Da gibt es nur punktuelle Erfahrungen und äh Dinge, die man als Quellen gelesen hat 
(22). Da fällt mir dieser wunderbare Film ein zum, zum, zur Rettung der Kunstwerke [...] 'Monuments Men' [...]. Da ging es doch um die Rettung der Kunstwerke, die aus ähm, die zusammengeraubt wurden, [...] und ähm dann versteckt und anschließend, ja, im Film von den Amerikanern gerettet wurden (23). Das ist aber nur eine Seite [...] (24). Es gibt eine ähnliche Geschichte für die Kunstwerke in Dresden. Da haben sie die Russen aus dem Stollen geholt [...] (25). Für mich war das höchst interessant, [...] der/ (...). Clooney [...], der erklärte die Aufgabe der amerikanischen Armee bezüglich der Rettung der deutschen Kunstwerke [...] (26). [B]in ich so groß geworden mit den Geschichten, dass von den Russen, und jetzt kommt für mich die/ es war ein Wissensgewinn [...] (27). Und wir haben ja gedacht, ach die Amis, die waren ja immer so schlecht, und das war ja alles sowieso nicht so gut, und dann ist daraus der Westen entstanden, ja (28). Ähm das, [...] da wurde in meinem Kopf auch noch mal was gerade gerückt[.] ${ }^{28}$

(21) I think this is very controversial. [...] There are realms of experience. And then it also depends on the eye of the beholder, which side of the border one grew up on. [...] There are only selective experiences and things you read as sources. (22) I remember this beautiful movie [...] Monuments Men [...] about rescuing artwork that had been robbed [...] and hidden and was then rescued by the Americans, according to the movie. (23) But that is only one side. (24) There is a similar story in Dresden, [where] the Russians took [artwork] out of a mine tunnel. (25) It was extremely interesting for me how [...] [George] Clooney [...] explained the task of the American army regarding the rescue of German artwork [...]. (26) I grew up with the stories about the Russians, [so] this was new knowledge [...]. (27) And we used to think that those Americans were always so bad, and that it all wasn't good, and that the West resulted from it [...]. (28) That sorted out something in my mind[.]

Julia suggests that the different views on the Western allies are equally legitimate: She refers to differences in experience, the geographical position, the 'eye of the beholder', and the selectiveness of historical sources (21). However, she expresses great surprise over learning that the Americans were not only 'bad' (26-27) but devoted themselves to Germany just as the Russians did (26). Whereas the Russians' good deeds are a given to her, the idea of American good deeds is a 'new knowledge'. Rather than reversing her ideas of good guys and bad guys, Julia identifies 
good in both sides, thus constructing a narrative that can be summarised as 'sometimes the West is as good as the East'.

\section{The Variety of Accounts in Different Classroom Situations}

When teaching the Cold War in class, Julia constructs three different types of accounts that correlate with different forms of interaction. The narrative templates of her life story are developed accordingly. I will first look at two situations in which Julia speaks uninterruptedly and constructs a relatively coherent historical account. In the first lesson, she has the students discuss a cartoon depicting a horse that Franklin D. Roosevelt and Winston Churchill ride in one direction and Josef Stalin in another. Standing in front of a wall map of central Europe, Julia produces the following monologue:

(29) Und das ist [...] hier die Scheidewand zwischen diesen beiden Systemen [deutet Grenze zwischen Ost- und Westeuropa an]. Für uns das hier [deutet Grenze zwischen Ost- und Westdeutschland an] [...] (30) Da passiert jetzt was ganz Besonderes. (31) Wer sich nicht leiden kann und sich nicht anguckt, der spricht nicht miteinander. (32) Der zieht in Gedanken eine Grenze [...]. (33) Der zieht politisch eine Grenze. (34) Der zieht eine Grenze wirtschaftlich. (35) 'Dir borge ich keinen Kuli. Du kannst mich mal. Was, du hast was vergessen? Dann sieh doch zu, wie du klarkommst. Mit dir nicht'. (36) Ich stelle mal noch ein paar Forderungen. Ich will dies, das und jenes haben. Sprich, Reparationen. [...] (37) Aber dann ist es Rille. (38) Es schließt sich jetzt hier zwischen diesen beiden Teilen Deutschlands [...] (39) Der eine der demokratisch geführte, und der andere der in diese Richtung geführte [deutet in Richtung Ost] [...]. (40) Da schließt sich wie so ein Vorhang. [...]. (41) Und wenn der Vorhang unten ist, dann sieht man nicht mehr, was auf der anderen Seite passiert. Dann hört man vielleicht noch was, aber das ist alles nur schon noch die Hälfte [...]. (42) So entstehen Gerüchte, falsche Meldungen (43). Und in dem Moment: ' $\mathrm{Na}$ ja, bei euch ist das ja jetzt so. Bei uns so', entwickeln sich die beiden Staaten auseinander [...]. (44) Hier senkt sich wie im Theater jetzt ein Vorhang. (45) Die in, in der [...] sowjetischen Besatzungszone, [...] wissen nicht mehr, was im Westen passiert. Und umgedreht. ${ }^{29}$ 
(29) [T]his [...] is the dividing line between these two systems [indicates line between Eastern and Western Europe]. For us, it's here [indicates line between East and West Germany] [...] (30) Something exceptional is happening here now. (31) If people don't like each other and don't see each other, they don't talk to each other. (32) They draw a mental line [...] (33) They draw a line politically. (34) They draw a line economically. (35) 'I won't lend you a pen. Go to hell. You left something at home? Don't come to me for help' [...] (36) I make a couple of demands [...] Reparations, that is [...] (37) But then I couldn't care less. (38) It's closing down now between these two parts of Germany [...] (39) The one that is democratically ruled and the other one that is ruled in this direction [points towards the East] [...] (40) It's like a curtain that is closing [...] (41) And once the curtain is down, you can no longer see what is happening on the other side. You might hear something, but only partially [...] (42) That's how rumours and false reports develop. (43) And at that moment: 'where you are, it's like this. Where we are, it's like that', the states are drifting apart [...] (44) Like in a theatre, a curtain is closing here now (45). Those [...] in the Soviet occupation zone [...] don't know what is going on in the West anymore. And vice versa.

While telling the story of German division, Julia re-applies elements of the narrative template 'nation and family' as well as the strategy of not assigning agency. The theme of division is translated into multiple metaphors. Starting out from the geo-political 'dividing line between these two systems' (29), which she physically indicates on the map, Julia first transfers the divide onto the abstract level of a 'mental line' (32). This connects the political sphere to everyday realities where people 'don't like each other', 'don't see each other' and consequently 'don't talk to each other' (31). The Cold War is thus constructed as a conflict that simultaneously takes place on a personal and political level, resembling Julia's description of the break than ran through her family and separated her Eastern and Western relatives. She continues to intertwine these spheres: The same people who draw a mental line also draw 'political' and 'economic' 'lines' (33-34). The fictitious person who demands reparations (36) is the same who 'won't lend you a pen' (35).

The intermingling of the political and personal level is epitomised in the metaphor of the curtain, borrowed from the concept of the Iron Curtain that, according to a speech by Winston Churchill from 1946, 
separated the Soviet sphere from the West. Julia also employs this metaphor to emphasise the idea of 'division', but she transfers it onto the level of everyday life, where 'you can no longer see what is happening on the other side' (41) and have to rely on 'rumours and false reports' (42) while developing a sense of 'us' versus 'them' (43). The emphasis of the metaphor thus shifts from the iron wall that painfully separates people to a curtain that hinders visual contact and thus encourages mutual stereotyping. The political component is only re-introduced when Julia finally refers to the two sides as 'the Soviet occupation zone' and 'the West' again (45).

Julia's curtain metaphor also moves the focus away from finding a scapegoat. By generalising the concepts of conflict and division, she supports the notion that the early Cold War was a conflict between two equals. At the end, the curtain is the actor that is 'closing' (40), forcing people in both occupation zones to become ignorant of each other (45). Once again, the blending of the spheres relies on a lack of agency. The Eastern part of Germany 'is ruled' in a particular yet not further specified way (39), 'rumours and false reports' appear to 'develop' by themselves (42), and 'the states are drifting apart' without any apparent agent (43).

In a lesson about the air strikes on Dresden in February 1945 and the aftermath, Julia draws on the notion of division and conflict to construct the Cold War as a story of reconciliation. She re-employs her 'specific narrative' about the moral standing of the Russians and the Americans:

Julia: (46) Da hat man ja in Dresden sämtliche Kunstgegenstände versucht, in Sicherheit zu bringen, indem man diese schönen Gemälde in Kisten verpackt in irgendwelche Bergwerksschächte verfrachtet hat. [...] (47) Anschließend gehen die Gemälde nach Moskau zur Restauration und werden dann drei, vier Jahre später wiedergebracht und dann erst wird in Dresden eine neue Galerie der alten Meister aufgebaut. [...] (48) Diese anderen Gebäude in Dresden an der Elbe, die das schöne Panorama immer ausmachen bei jeder Sendung über Dresden, die waren Zentrum, Angriffspunkt, dort war platt. Da war alles platt. [...] (49) So, Dresden. Hier (ziemlich bei uns). [...], auch mit dem (Herzen). [... (50) Bombardiert hat wer? Welche Fliegerverbände waren denn das? [...] 
Julia: (46) In Dresden they tried to secure all the works of art by putting these beautiful paintings in boxes and storing them in mine tunnels. [...] (47) Afterwards, they were taken to Moscow for restoration and returned three, four years later, and only then a new gallery of the old masters was built in Dresden. (48) The [...] buildings by the riverside [...], always shown in attractive panorama shots in television programmes about Dresden, were the centre, the point of attack. That was all flattened. (49) Here, relatively close to us, also to our hearts. (50) Who did the bombing? Which bomber squadron?

Student: (51) Die Amerikaner?

Student: (51) The Americans?

Julia:

(52) Die angloamerikanischen Kriegsverbände. [...] Die [Frauenkirche] hatte so ein schickes Kreuz auf dem Altar stehen. Und das ist in dieser Bombennacht kaputtgegangen (53). Also als die Frauenkirche vor vier Jahren wieder eingeweiht wurde, haben die Amerikaner und die Briten aus Spendengeldern ein neues Kreuz dieser Art für die Frauenkirche gespendet und praktisch überreicht (54) [...]. Das ist richtig schick mit ganz vielen Edelsteinen. Also es war sehr/ Es war wirklich ein tolles [...] und wertvolles Stück. (56) Und das hat man den Dresdnern wiedergeschenkt. [...] So, die Dresdner haben sich wahnsinnig gefreut.

Julia: (52) The Anglo-American army groups. [...] (53) The Frauenkirche [Church of Our Lady] had a lovely cross on its altar, [which...] was destroyed during this night of bombing. (54) When the Frauenkirche was re-inaugurated four years ago, the Americans and the British donated a new cross of the same kind ... and formally presented it. (55) It's huge [and] [...] truly impressive, with many gemstones [...]. It was really a wonderful and valuable object. (56) And that was given back to the people of Dresden. [...] (57) The people of Dresden were delighted. ${ }^{30}$ 
The narrative template of 'reconciliation' provides the basis of this account. Just as in Julia's life story, the concept of a successfully solved conflict thus features prominently. Taking up the topic of rescued artwork, she marks the final phase of World War II as the beginning, and the present age as the end of a conflict between the Americans and British on the one hand and the people of Dresden on the other. By pointing out the merits of the new cross (55) and how delighted the people were (57), she represents the donation as a gesture that finally ended hostilities. The Cold War, as the intervening period, has thus come to a happy end.

The narrative template of reconciliation comes along with the reemployment of the idea that the Americans became as good as the Russians had always been. In the first part of the dialogue, Julia portrays the Russians as rescuers, restorers and donors of 'beautiful' and culturally significant artwork (46-47) in a city we are all fond of (49). Implicitly creating a contrast between 'us' and the Western allies, she then lets the students conclude that the Americans and British were responsible for the bombing (50-51). The two sides are reconciled when the Americans and British donate an extraordinarily 'impressive' and 'valuable' (55) cross, i.e. when they show themselves as devoted to art culture, and hence the people of Dresden, as the Russians did.

Not all of Julia's Cold War accounts in class are reconciliatory. In the following, I will analyse more interactive situations, beginning with a unit about the different political and social orders in the future occupation zones. Talking about changes in Germany after 1945, Julia first portrays the Western powers, especially the US, in a traditional Western fashion as representatives of democracy:

Julia: (58) Könnt ihr mir bitte sagen, [...] in welcher Gesellschaftsstruktur die Amerikaner ' 45 gelebt haben? [...] Was ist das für ein Land? Wer regiert? Wer hat die Regierung dahin gesetzt? Wie ist dieses Land gesellschaftlich aufgeteilt? [...]

Julia: (58) Could you please tell me [...] in what social order the Americans were living in 1945? [...] What kind of a country is that? Who rules it? Who put the government in power? [...] 
Student. (59) In Demokratie.

Student. (59) [In a] democracy.

Julia: (60) Sehr schön.

Julia: (60) Very good.

[After elaborating on the roles of Britain and France, Julia writes on the blackboard: 'USA, GB, FR democracy'.] ${ }^{31}$

When continuing about the Western economic system, however, Julia brings in an element of an interpretation that was officially supported by the GDR:

Julia: Wer besitzt die Cola-Fabriken, die Jeans-Fabriken, Autofabriken? Wer besitzt Geschäfte? [...] [I]ch will das Prinzip wissen. [...]

Julia: (61) Who owns the Coca-Cola factories? The jeans factories? The car factories? I [...] want to know the principle. [...]

Student. (62) Ja, dem, dem die Fabrik gehört.

Student. (62) Well, whoever owns the factory.

Julia: (63) Genau. Da ist eine Privatperson der Besitzer. [...] Das ist also ein privatwirtschaftlich organisierter Staat. Man nennt das auch kapitalistisch oder imperialistisch. [...] (64) So, jetzt brauche ich hier die Mitte der Tafel. [...] (65) Und jetzt die Frage, wie ist das in der Sowjetunion [...]?

Julia: $\quad$ (63) [...] Exactly. A person has private ownership [...] So it's a privately organised state economy. This is also called capitalist or imperialist. (64) Alright [...] Now I have to write in the middle of the board. [For the US, Britain and France, she writes 'capitalist/imperialist (private ownership of capital goods)' on the blackboard.] Property is also privately owned by individual people. (65) And now the question is, what about the Soviet Union? ${ }^{32}$

Mixing elements of Eastern and Western narratives, Julia produces mixed representations of Cold War actors. What is striking is her use of the term 'imperialist', a concept frequently used to describe the West in traditional 
Eastern and revisionist interpretations. Casually dropping the term in as a mere synonym for 'capitalist', Julia equalises the principle of 'private ownership' with imperialism (63). She does not specify on the blackboard that this refers to the economy. Consequently, the terms 'capitalist/ imperialist' can be read right underneath the term 'democratic', all of which are listed as features of the Western powers. The equalisation of 'capitalism' with the clearly negatively connoted term 'imperialism' is not clarified or discussed. Even when a student later asks 'what it says there' next to 'capitalism', Julia merely repeats 'imperialist', which the student then copies into his exercise book. ${ }^{33}$

The mixing of discourses with the resulting ambivalence also affects the representation of the Soviet Union. In one lesson, a student is asked to repeat some of the contents from a previous lesson at the wall map:

(66) Student: Berlin. Wurde von den Sowjet/ von den, von der Sowjetunion besetzt. [...]

Student: $\quad[\ldots]$ Berlin wurde halt auch in vier Teile geschnitten sozusagen. $[\ldots]$

Student: $\quad[\ldots]$ Die Briten haben den westlichen Teil besetzt. Die F/ ähm Franz/ die/

(66) Student: Berlin [was] occupied by the Soviet Union. [...]

Student: $\quad[\ldots]$ Berlin was also cut into four pieces [...]

Student. $\quad[. .$.$] The British occupied the Western part. [...] The Fre$ [...]

Julia (67) Nein, die Amis.

Julia: (67) No, the Yanks.

Student. (68) Die Amis haben den südlichen Teil besetzt und die Sowjetunion den östlichen Teil.

Student. (68) The Yanks occupied the southern part and the Soviet Union the Eastern part. [...]

Student. (69) [...] $\mathrm{Zu}$ den politischen Problemen gehörte, dass die vier Länder aufeinander trafen. [...] Sie wollten die sozusagen Demokratie machen.

Student. (69) [...] One of the political problems was that those four countries encountered each other [...]. They wanted to make democracy, so to speak. 
Julia: Die Sowjetunion auch?

Julia: $\quad$ (70) The Soviet Union, too?

Student. (71) Nee, die Sowjetunion nicht. Nur die Frankreich, Amerika und die britische. [...]

Student. (71) Nope, not the Soviet Union. Only France, America and the British. [...]

Julia:

(72) Bei Berlin aufpassen: Es wurde tatsächlich äh hier von der Roten Armee die Befreiung ähm geschafft. Und dann erst die Einteilung, du hast das Wort 'geschnitten' benutzt, kann man ruhig sagen. Es passt da irgendwo an diese Stelle, mhm (zustimmend). Gut. So. Das ist Deutschland. Jetzt frage ich dich [...] nochmal: Du hast irgendwann mal gesagt, du hast einen Ausflug gemacht in eine dieser Weststädte. Wo warst du denn?

Julia: $\quad$ (72) Alright [...] Careful with Berlin: Its liberation was, in fact, achieved by the Red Army. Only then was it divided [...] (73) Now I'm asking you again [...]: You once said that you went on a trip to one of those Weststädte [towns in the West]. Where did you go? ${ }^{34}$

The Soviet Union is portrayed with a mix of traditionalist Western interpretations and a terminology stemming from traditional Eastern discourse. Whereas Julia makes the student re-construct the democracy-dictatorship dichotomy as the major political problem (69-71), she later states that the Red Army 'achieved' the 'liberation' of Berlin (72). Representing the Soviets as liberators, she employs an essential element of official GDR narrations of the post-World War II period. This is supported by the formerly pejorative colloquial term 'Amis' (Yanks) (67), which has its origins in the post-World War II and early Cold War period (the slogan 'Ami, go home!' was upheld especially by the GDR). ${ }^{35}$ By finally referring to certain German cities as 'those Weststädte', Julia employs another term that is based on a clear division between East and West. She thus re-creates the same 'us' versus 'them' mentality she explicitly criticises in the previously analysed lesson. Again, none of the contradictions are identified, discussed or clarified. 
In the final classroom situation, Julia reconstructs former GDR discourse when interacting with the students and dealing with the textbook. As for post-World War II history, the textbook from the series Entdecken und Verstehen, published by Cornelsen, takes a traditional Western perspective on the Soviet Union (Christophe 2017). Regarding denazification in the Soviet occupation zone, it says:

Mit der Parole von der 'Ausrottung der Überreste des Faschismus' wurden die bisherigen Eliten in Schule, Justiz, Verwaltung, Polizei und Wirtschaft radikal entmachtet und durch Sozialisten bzw. Kommunisten ersetzt. Die Kommunisten nutzten die Entnazifizierung aber auch, um politische Gegner $[\ldots]$ auszuschalten. So wurde die Entnazifizierung hier zum Mittel kommunistischer Herrschaftssicherung. [...] Die SED ging davon aus, dass die antifaschistische Gesinnung wichtiger sei als Fachkenntnisse [...]. Andererseits wurden bereits nach wenigen Jahren auch in der DDR viele ehemalige Fachleute wieder in staatlichen Funktionen (Polizei, Militär) eingesetzt, soweit ihnen nicht konkrete Vergehen angelastet wurden und wenn sie vor allen Dingen nur glaubhaft die 'richtige' Gesinnung zeigten (Entdecken und Verstehen, 25).

Under the slogan 'eliminating the remnants of fascism', the elites in the school, judiciary, administration, police and economy were radically disempowered and replaced by socialists and communists. But the communists also used denazification to eliminate political opponents [...]. Denazification was thus used as a means to secure communist power. [...] The SED assumed that an anti-fascist attitude was more important than expertise $[\ldots]$. On the other hand, in the GDR, too, many former experts were returned to their public offices (police, military) after only a few years as long as they were not accused of any specific misdeeds and, most importantly, if they could convincingly display the 'correct' attitude.

According to the text, denazification in the Soviet zone was flawed by communist ideology. While interacting with a student, however, Julia turns this interpretation into a 'successful denazification in the East' narrative. In the following scene, the student was asked to summarize the implementation of denazification in the Soviet zone as described in the textbook: 
Student. (74) $\mathrm{Na}$, Lehrer wurden entlassen und ersetzt durch Sozialisten und Kommunisten. Ähm Entnazifizierung wurde zum Mittel kommunistischer Herrschaftssicherung. Ähm es wurde klar unterschieden zwischen aktiven Nazis und Mitläufern. Äh in der DDR wurden ehemalige Fachleute äh wieder eingesetzt.

Student. (74) Well, teachers were released and replaced by socialists and communists. Denazification was used as a means to secure communist power. [...] (75) In the GDR, former experts were put back in office.

[Meanwhile, Julia writes on the blackboard: teachers released, communists take over positions.]

Julia: (76) Gut. Ihr habt mitgeschrieben. Richtig. (77) Hier ist es klar. (78) Vorhin haben wir noch gefragt, was ist in den anderen Besatzungszonen los? Was ist in den Ämtern los? (79) Wahrscheinlich, heißt es, die Amerikaner übernehmen oder die Briten oder die Franzosen. (80) Und hier ist es klipp und klar, raus mit den Nazis. (81) Und an ihre Stelle kommen alle die, die sich äh während der Nazizeit in einer kommunistischen Partei oder auch in einer sozialdemokratischen Partei engagiert haben.

Julia: (82) Good. You have all copied from the board. Right. (83) It's a clear case. (84) Earlier, we asked: what is happening in the other occupation zones? What is happening in the offices? (85) Probably, it says, the Americans took over or the British or the French. (86) And here it's clear as day: out with the Nazis. (87) And their positions are taken over by all those who were active in communist or social democratic parties during Nazi times. ${ }^{36}$

The student, who does not seem disturbed by the textbook account, correctly repeats its major claims. Julia, however, tacitly turns the traditional Western portrayal on its head. On an explicit level, she agrees with the student's summary ('good', 'right' [82]) and hence with the textbook account of denazification in the Soviet occupation zone. Her highly selective notes on the blackboard ('teachers released, communists take over 
positions'), however, provide the ground for transferring this account to match former GDR narratives. Catching merely the first and relatively neutral point of the student's summary, they ignore the aspects that mark the narrative as traditionally Western, i.e. the claims that the communists used denazification for their own purposes and that former Nazis were put back in office. This reduction of the text makes it possible for Julia to develop the contrary argument that, in East Germany, 'it's clear as day: out with the Nazis' (86). She backs this up by contrasting the situations in the East and West zones (84-86). Again, the East is constructed as the model for success against which the West is measured and with which the latter cannot compete this time, thus reversing the textbook's logic. Finally, Julia turns the communists and socialists who, according to the text, took over the positions, into communists and social democrats (87). This small alteration has significant consequences, as it deconstructs the idea that denazification in the East was used to eliminate political opponents.

\section{Conclusion}

This study has explored how a teacher of the 'integrated generation' relates to contemporary Cold War discourse in different contexts and situations. My analysis shows that Julia has developed a repertoire of accounts of the Cold War consisting of both individual narratives and underlying narrative templates. She employs the concept of 'reconciliation' for constructing her life story as well as for evaluating textbooks and teaching history. She thus de-politicises the historical conflict while also attributing a political component to the division within her family. This twofold process also applies to the template of the 'victim', which she uses to describe her father's situation in GDR times. While the spheres of 'family' and 'nation' become deeply intertwined, the non-assignment of agency weakens the political element: It remains obscure who is responsible for the division and thus for the victimisation.

In class, the mixing of the spheres and the non-assignment of agency recur in reconciliatory accounts of the Cold War. Other classroom situations triggered different accounts. In student-teacher dialogues, Julia 
constructed ambivalent images of the two major actors by combining traditional Eastern and Western patterns of interpretation. When including the traditional Western textbook as an additional authority, and thus relinquishing her own level of control to a certain extent, she resorted to former GDR narratives.

While Julia seems to have acquired some traditionally Western ideas, these instances suggest an internalisation of GDR discourse. This ambivalent condition expresses itself in narratives such as 'the West is sometimes as good as the East', in which she turns around the logic by measuring the West against the East.

The fact that Julia reinterprets narratives not by openly criticising but by tacitly altering them confirms James C. Scott's observations about resisting hegemonic ideas in social contexts with asymmetrical powerrelations. According to Scott, whose subject of study was a group of Malaysian peasants in the 1970 s, such resistance usually does not occur in the form of conscious and articulated revolution, but (partly) by constructing alternative narrations on the basis of shared norms (Scott 1985). Julia's acts of reinterpretation can thus be seen as a form of negotiation that avoids fuelling antagonism and hostility. This also indicates that it is still taboo to openly challenge presumably official versions of history in Germany. The instance of resorting to GDR narratives as a reaction to the textbook's one-sided view on denazification in the Soviet zone can then be read as an escape mechanism; it may result from not daring to publically deconstruct a perspective on the GDR that is considered socially dominant. The teaching of recent history thus reveals a severe lack of discussion.

The ambiguity Julia produces when dealing with the past also reveals a broader challenge that members of the 'integrated generation' face: Given that the GDR is primarily viewed as a failed dictatorial regime today, the values with which this generation grew up can no longer serve as a 'cultural supply' of acceptable means to construct a life story (Linde 1993). Instead, members of this generation are urged to adapt the images they construct of themselves to new expectations, which, however, remain vague and unspoken. In the course of this study, we have encountered traces of a considerable gap between the way in which Julia experiences and positions herself towards Cold War discourse and the way in which 
the students relate to it. More research on the younger generation is needed to enrich the debate and contribute to our understanding of how the legacy of the GDR and the history of the Cold War are dealt with in Germany.

\section{Notes}

1. Both publications refer to the Sächsische Längsschnittstudie, which has analysed the transformation of (young) Eastern Germans from GDR into FRG citizens since 1987. http://www.wiedervereinigung.de/sls/ index.html (accessed 22 February 2017).

2. Cf. this and the previous sentence with Chapter 13 of this volume, by Barbara Christophe.

3. As Reh points out, some actors, such as the union Erziehung und Wissenschaft (Education and Science), had a more differentiated view on education in the former GDR (ibid., 112-113).

4. Real name withheld.

5. The material was collected between June and November 2014 by Kathrin Zehr, whom we would like to thank for her support. The interviews and lessons were recorded, transcribed, and rendered anonymous by giving code names to persons and places mentioned. As a rule I quote from them by indicating the file name and the location of the quote in minutes of recording as indicated in the transcription. The quotes I use in the text were translated from German by the author. The original files can be consulted at the Georg Eckert Institute in Braunschweig on the basis of respecting and guaranteeing the privacy rights of the people involved.

6. See his concept of 'cultural tool' in Wertsch 2002.

7. In his development of the concepts of 'specific narratives' and 'schematic narrative templates', Wertsch draws on MacIntyre 1984 and Propp 1968.

8. 'Ja, dieses freie Kindsein, wir haben das gelebt'.TCW_Biogr_9_SA.doc, \#00:18:14-2\# - \#00:19:19-9\#, \#01:21:49-6\# - \#01:22:45-5\#; 'Wir haben gespielt und sind da äh durch die Siedlung getobt und haben uns vergnügt.' Ibid, \#00:01:41-2\#-\#00:04:08-3\#.

9. 'Und wir hatten auf der gleichen Etage, wo mein Vater wohnte, nebenan so eine geteilte Wohnung. Die hat nur 10 Mark gekostet. [...]Ach so, 
wir haben fürs Kind auch noch mal 60 Mark gekriegt im Monat. Ja. Da gab es noch diese Unterstützung für Studenten mit [...] Kind. Wir waren, glaube ich, der erste Jahrgang, bei dem das da so alles mit diesen Sozialmaßnahmen dann kam.' Ibid, \#00:47:05-7\# - \#00:49:29-5\#.

10. ' $[. .$.$] die Wende. [...] Die war für mich enorm.' Ibid, \#01:49:25-8\# -$ \#01:50:14-4\#.

11. 'Na ja, vor der Wende schon, dieses 89er Jahr dann. [...] Aber, hm, [...] man hatte selber die Fragen im Hinterkopf, was wird? Und wie geht das hier alles weiter?' Ibid, \#01:43:36-9\# - \#01:46:28-8\#.

12. 'Wende und Schulsystem. Ja, das war schon hart. Ich habe am 19. November, wenn das der Montag war, eine Klassenarbeit schreiben wollen. Thema: "Die Mauer", 19. November '89. Das war also wochenlang vorher Thema. Ähm, hm. An dem Tag saßen sieben Schüler in der Klasse mit der Bild-Zeitung bewaffnet. (Laughs) Ich habe diese Klassenarbeit nicht geschrieben, aber ich war irgendwo dem Koma nahe'. Ibid, \#01:32:04-0\# - \#01:38:02-7\#.

13. 'Da gab es dann ein paar wenige Gespräche dazu, aber der ist auch ' 96 verstorben, also [...] er konnte das nicht mehr voll genießen.' Ibid, \#00:53:21-5\# - \#00:55:46-3\#.

14. 'Nach der Wende. Ich habe dann sämtliche Bücherläden wieder mal und immer noch und, ja, na das, das ist dann so, ja, wenn man einmal den Anstoß hat und Franziska Linkerhand gelesen hat, dann muss man auch wissen, was ist denn $\mathrm{da}$ in der anderen Seite los?' Ibid, \#01:21:49-6\#-\#01:22:45-5\#.

15. 'Und dann hat [die Staatsbürgerkundelehrerin] unterrichtet, was im Lehrplan steht. [...] Sie hat sich da schon klar positioniert. Auch bei den anderen Klassenlehrern so.' Ibid, \#01:05:30-2\# - \#01:06:42-4\#.

16. 'Da standen Daten, Daten, Daten, [...] ähm DDR-Gründung, ähm SED-Gründung aus der und der dann und dann das und das. So. "Lesen Sie dort und dort nach." Und das war ein Werk, was natürlich von einem der Mit/ Mitläufer, Mitmacher äh geschrieben wurde, also unkritisch. Also nur heroisch dargestellt.' Ibid, \#01:17:32-7\# - \#01:19:24-9\#.

17. 'Genau, die [Fragen] wurden abgebogen. [...] Ich habe brav das Wissen aufgesogen.' Ibid, \#01:17:38-5\#-\#01:19:24-9\#.

18. 'Ja, wenn, wenn ich dran denke, wie das in den 68er-Kreisen eigentlich war, wir haben dann hier "Blutige Erdbeeren" angeguckt und haben gestaunt, dass man sich als Studenten äh so engagieren und so aufreiben kann. [...] Ich glaube, da haben wir zum ersten Mal drüber nachge- 
dacht, ob man das mal machen sollte. [...] Aber nie ernsthaft irgendwo in eine Richtung. Da waren wir vielleicht auch schon wieder zu sanft und haben uns gesagt: "Och, es geht uns doch eigentlich ganz gut."[,].' Ibid, \#01:23:54-2\# - \#01:25:56-8\#.

19. 'Ja, und irgendwann zwischen ' 51 und ' 52 haben sich meine Eltern dann (fester) gefunden und '54 geheiratet. [...] Ja, und dann haben sie das getan, was alle taten, irgendwo die Grundlagen legen für [...] das gemeinsame Nest. Ja, und weil ähm eben diese Flüchtlingsgeschichten dahinter stecken, ist das ja so neues Wurzelnsuchen oder Wurzelnbilden.' Ibid, \#00:18:14-2\# - \#00:19:19-9\#.

20. 'Und das hat sich ergeben, weil er mit seiner Familie [...] aus Ostpreußen äh geflüchtet ist. Hier dann 1945 ankam und sich praktisch neu orientieren musste.'Ibid, \#00:15:24-7\# - \#00:19:19-9\#.

21. 'Da gab es [...] so einen Befehl, wo sich die Angehörigen dieser Einrichtung von ihrer Westverwandtschaft lossagen mussten. [...] Und ich denke, deswegen ist auch die Beziehung schwer belastet gewesen.' Ibid, \#00:24:05-9\#-\#00:27:09-0\#.

22. The numbers in brackets are added by the author for the reader's orientation.

23. Ibid, \#00:27:09-0\# - \#00:29:44-2\#.

24. Ibid, \#00:53:21-5\# - \#00:55:46-3\#.

25. Ibid, \#00:55:50-7\# - \#00:56:55-0\#.

26. 'Ich denke, da hat jedes politische System seinen Teil zu beigetragen. Indem man eben bestimmte Machtbereiche abgesteckt hat und bestimmte wirtschaftliche Interessen ähm bedienen wollte'. TCW_Amb_9_ SA.doc, \#01:34:48-8\# -\#01:35:10-5\#.

27. 'Rohstoffe, [...] ähm auch Märkte. [...] Letztendlich um Geld in der Wirtschaft'. Ibid, \#01:35:18-7\# - \#01:35:30-1\#.

28. Ibid, \#00:44:15-1\# - \#00:47:12-0\#.

29. 2014-11-14_Vid-L_9_SA.doc; 2014-11-14_Vid-L_9_SA.avi，\#00:40: 11-9\# - \#00:43:04-2\#.

30. 2014-09-26_Vid_9_SA.doc; 2014-09-26_Vid_9_SA.avi; \#00:11:06-1 \# -\#00:14:10-8\#.

31. Ibid; \#00:31:49-6\#-\#00:34:44-3\#.

32. Ibid; \#00:34:48-8\#-\#00:36:37-0\#.

33. Ibid; \#00:37:47-9\#-\#00:37:53-6\#.

34. 2014-10-24_Vid-L_9_SA_a.doc; 2014-10-24_Vid-L_9_SA_a.avi; \#00: 04:45-4\# -\#00:07:40-3\#. 
35. This slogan partly became popular through the song 'Ami, Go Home' by Ernst Busch, published in his Internationale Arbeiterlieder of 1953 (142144). See the lyrics at erinnerungsort: Materialien zur Kulturgeschichte: http://www.erinnerungsort.de/Ami-2C-go-home-21-_88.html (accessed May 15, 2018).

36. 2014-10-24_Vid-L_9_SA_a.doc, \#00:43:48-0\# - \#00:45:00-6\#.

\section{Bibliography}

\section{Textbook Cited}

Entdecken und Verstehen 10. Vom Ende des Zweiten Weltkriegs bis in die Gegenwart. 2010. Thomas Berger-v. d. Heide, Stephan Burrichter, Bettina Mende, Ulrich Mittelstädt, Karl-Heinz Müller, Dieter Potente and Cornelius Schley. Berlin: Cornelsen.

\section{Further References}

Ahlrichs, Johanna, Katharina Baier, Barbara Christophe, Felicitas Macgilchrist, Patrick Mielke and Roman Richtera. 2015. 'Memory Practices in the Classroom: On Reproducing, Destabilizing and Interrupting Majority Memories'. Journal of Educational Media, Memory, and Society 7, no. 2: 89-109.

Baier, Katharina, Barbara Christophe and Kathrin Zehr. 2014. 'Schulbücher als Seismographen für Diskursive Brüche: Ein Neuer Ansatz in der Kulturwissenschaftlichen Schulbuchforschung Dargestellt am Beispiel der Analyse von Schulbucherzählungen über den Kalten Krieg', Eckert. Working Papers 4. http://www.edumeres.net/urn/urn:nbn:de:0220-2014-00184, last accessed 23 October 2018.

Binnenkade, Alexandra. 2015 'Doing Memory: Teaching as a Discursive Node', Journal of Educational Media, Memory, and Society 7, no. 2: 29-43.

Christophe, Barbara. 2017. "Eigentlich hingen ja alle mit drin.” Entnazifizierung und Kalter Krieg in deutschen Schulbüchern und in den Erzählungen von Lehrenden'. In Das Geteilte Deutschland im Schulbuch: Die Darstellung des Kalten Krieges am Beispiel Deutschlands in den (Geschichts-) Schulbüchern von 
1945 bis in die Gegenwart, edited by Franziska Flucke and Ulrich Pfeil, 147-164. St. Ingbert: Röhrig Universitätsverlag.

Erll, Astrid. 2011. Kollektives Gedächtnis und Erinnerungskulturen: Eine Einführung. $2^{\text {nd }}$ rev. ed. Stuttgart/Weimar: Metzler.

Feindt, Gregor et al. 2014. 'Entangled Memory: Toward A Third Wave in Memory Studies'. History and Theory 53: 24-44.

Förster, Peter. 2008. 'Noch Immer Keine Zukunft im Osten! Bericht über Wesentliche Ergebnisse der 22. Welle', http://www.wiedervereinigung.de/sls/ PDF/foersterstudie2009.pdf, accessed 22 February 2017).

Förster, Peter. 2011. 'Zwischenbilanz: Zwei Jahrzehnte nach Wende und Deutscher Einheit ist die Generation der Mittdreißiger tief gespalten in Gewinner und Verlierer!' Ergebnisbericht zur 23. Welle der Sächsischen Längsschnittstudie. Leipzig,. http://www.wiedervereinigung.de/sls/PDF/ foersterstudie2010.pdf, accessed 22 February 2017.

Foucault, Michel. 1969. L'Archéologie du Savoir. Paris: Gallimard.

Iriye, Akira. 2014. Global Interdependence: The World after 1945. Cambridge, Massachusetts [u.a.]: The Belknap Press of Harvard Univ. Press.

Jarausch, Konrad H., Christian F. Ostermann and Andreas Etges, eds. 2017. The Cold War: Historiography, Memory, Representation. Berlin: De Gruyter.

Kleßmann, Christoph. 2010. '1945: Welthistorische Zäsur und "Stunde Null”, Version 1:0’. Docupedia-Zeitgeschichte 15 October 2010. http://docupedia. de/zg/1945, accessed 23 October 2018.

Lindner, Bernd. 'Kriterien für ein Modell der Jugendgenerationen in der DDR'. In Generationalität und Lebensgeschichte im 20. Jahrhundert, edited by Jürgen Reulecke, 187-215. München: R. Oldenburg Verlag, 2003.

Linde, Charlotte. 1993. Life Stories: The Creation of Coherence. New York/ Oxford: Oxford University Press.

Lundestad, Geir. 2014. East, West, North, South: International Relations since 1945. $7^{\text {th }}$ ed. Los Angeles: Sage.

MacIntyre, Alasdair C. 1984. After Virtue: A Study in Moral Theory. Notre Dame, Indiana: University of Notre Dame Press.

Möller, Horst. 1995. 'Die Relativität Historischer Epochen: Das Jahr 1945 in der Perspektive des Jahres 1989'. Aus Politik und Zeitgeschichte 18: 3-9.

Müller, Birgit. 2008. 'Erinnerungskultur in der DDR'. Geschichte und Erinnerung. Berlin: Bundeszentrale für Politische Bildung. http://www.bpb. de/geschichte/zeitgeschichte/geschichte-und-erinnerung/, accessed 24 October 2016. 
Propp, Vladimir. 1968. Morphology of the Folktale. Translated by Laurence Scott. Austin: University of Texas.

Reh, Sabine. 2003. Berufsbiographische Texte ostdeutscher Lehrer und Lehrerinnen als 'Bekenntnisse': Interpretationen und methodologische Überlegungen zur erziehungswissenschaftlichen Biographieforschung. Bad Heilbrunn: Klinkhardt.

Scott, James C. 1985. Weapons of the Weak: Everyday Forms of Peasant Resistance. New Haven, CT: Yale University Press.

Welke, Tina. 2012. Tatort Deutsche Einheit: Ostdeutsche Identitätsinszenierung im 'Tatort' des MDR. Bielefeld: transcript.

Wertsch, James V. 2002. Voices of Collective Remembering. Cambridge: Cambridge Univ. Press.

Schütze, Fritz. 1982. 'Narrative Repräsentation Kollektiver Schicksalsbetroffenheit'. In Erzählforschung: Ein Symposium, edited by Eberhard Lämmert, 568-590. Stuttgart: Metzler.

Open Access This chapter is licensed under the terms of the Creative Commons Attribution 4.0 International License (http://creativecommons.org/licenses/ by/4.0/), which permits use, sharing, adaptation, distribution and reproduction in any medium or format, as long as you give appropriate credit to the original author(s) and the source, provide a link to the Creative Commons licence and indicate if changes were made.

The images or other third party material in this chapter are included in the chapter's Creative Commons licence, unless indicated otherwise in a credit line to the material. If material is not included in the chapter's Creative Commons licence and your intended use is not permitted by statutory regulation or exceeds the permitted use, you will need to obtain permission directly from the copyright holder.

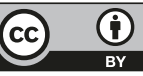

